\title{
Államadósság-csökkentés az EU régi tagállamaiban: van új a nap alatt?*
}

\author{
Losoncz Miklós - Tóth G. Csaba
}

A 2007-ben kezdödött, nagy recessziónak elnevezett nemzetközi pénzügyi és gazdasági válság, majd az azt követő szuverén adósságválság nyomán jelentősen megemelkedett az államadósság-ráta (a bruttó államadósság GDP-hez viszonyított aránya) az Európai Unióban. Ezután az EU régi tagállamaiban (EU15) olyan fokozatos és tartós konszolidáció kezdődött, amelyre utoljára az 1990-es évek közepétöl volt példa, és amelynek éppen a gazdasági válság vetett véget. Tanulmányunkban adósságdekompozíciós vizsgálat segítségével mutatjuk ki a 2010-es évek második felében végrehajtott, illetve a korábbi nagy recesszió kitörésével zárult államadósság-csökkentö idöszakok közötti legföbb hasonlóságokat és különbségeket. Mindkét periódusban az EU15 országcsoport közel kétharmadában éves átlagban közel hasonló mértékben mérséklődött az államadósság-ráta. E hasonlóság mellett azonban jelentős eltérések voltak a konszolidáció szerkezetében. Az 1990-es évek közepétöl a 2007-2009-es válságig tartó periódusban döntöen a fegyelmezett költségvetési politika dinamizálta az elsődleges egyenlegen keresztül az adósságcsökkentést, a reálnövekedés hatását ellensúlyozta a reálkamatláb hatása, az egyéb tételeknek pedig nem volt számottevö szerepük. Ehhez képest az elmúlt közel fél évtizedben tapasztalt adósságcsökkentésben sokkal kisebb volt a fiskális politika hatása, miközben a kamatlábak alacsonyabb szintje és az egyéb tételek érdemben segítették a konszolidációs folyamatot. A kedvező nemzetközi kamatkörnyezet elkényelmesítette a fiskális politikát. A monetáris politika támogatásának megszünése, illetve gyengülése esetén az EU15 országokban ismét felértékelödik a fiskális politikának az államadósság-ráta mérséklésében játszott szerepe.

Journal of Economic Literature (JEL) kódok: H63, H60, E62, E63

Kulcsszavak: fiskális politika, államadósság, EU15, adósságcsökkentés, költségvetési egyenleg, konszolidáció

* A jelen kiadványban megjelenő írások a szerzők nézeteit tartalmazzák, ami nem feltétlenül egyezik a Magyar Nemzeti Bank hivatalos álláspontjával.

Losoncz Miklós DSc a Budapesti Gazdasági Egyetem Pénzügyi és Számviteli Karának egyetemi tanára. E-mail: losoncz.miklos@uni-bge.hu

Tóth G. Csaba PhD a KSH Népességtudományi Kutatóintézetének tudományos munkatársa.

E-mail: toth@demografia.hu

A tanulmány az MTA-BGE Makrogazdasági fenntarthatóság kutatócsoport keretében, a Támogatott Kutatócsoportok Irodájának támogatásával készült. Losoncz Miklós a kutatócsoport vezetője.

A magyar nyelvű kézirat első változata 2020. március 16-án érkezett szerkesztőségünkbe.

DOI: http://doi.org/10.25201/HSZ.19.2.2854 


\section{Bevezetés ${ }^{1}$}

A 2007-2009. évi nemzetközi pénzügyi és gazdasági válságot ${ }^{2}$ megelőző közel másfél évtized nem hiába vonult be a történelemkönyvekbe a nagy mérséklödés (Bernanke 2004) időszakaként. A korábbi évekhez képest jelentősen enyhült a fóbb makrogazdasági mutatók volatilitása, és néhány kivételtôl eltekintve viszonylagos nyugalom jellemezte az európai uniós tagállamok költségvetési gazdálkodását is. Bár az egyes országok között jelentős különbségek voltak, az 1990-es években megkezdett, a rövid távú egyenlegjavítás szempontjából többé-kevésbé eredményesnek bizonyult költségvetési konszolidációk nyomán sikerült a GDP-arányos bruttó államadósság növekedési trendjét is megállítani, illetve megfordítani (Baldacci és szerzőtársai 2014). A nemzetközi pénzügyi és gazdasági válság azonban gazdaságtörténeti korszakhatárként egy pillanat alatt lezárta a költségvetési politika gondtalan éveit. Rákényszerítette a közgazdászokat és a döntéshozókat, hogy újragondolják a fiskális politikával kapcsolatos nézeteiket (Muraközy 2012). Erre többek között azért volt szükség, mert a pénzügyi, majd az annak talaján kialakult reálgazdasági válság néhány éven belül szuverén adósságválságot idézett elő az EU, illetve az euroövezet több országában, sőt máshol is. Több mint fél tucat állam kormánya volt kénytelen pénzügyi segítséget kérni különböző nemzetközi szervezetektől, hogy fizetési kötelezettségeinek eleget tudjon tenni (Tóth 2014, Tóth 2017, Losoncz 2014). Az általunk vizsgált probléma súlyát jelzi, hogy az Európai Bizottság még a 2019. évi középtávú elörejelzésében (European Commission 2019) is az uniós tagállamok közel felénél talált közepes vagy nagy kockázatot az állam pénzügyeinek fenntarthatóságával kapcsolatban ${ }^{3}$.

Érthető tehát, hogy az európai államok többsége a nagy recesszió, majd az azt követő szuverén adósságválság után megpróbálta konszolidálni költségvetése helyzetét, fokozatosan javította az egyenleget és mérsékelte az adósságrátát. A fiskális és konjunkturális pozíciókra vonatkozó jelentős eltérések miatt a fordulatra nem ugyanakkor került sor minden országban, 2015-ben azonban megkezdődött az EU15-ök átlagos adósságrátájának csökkenése is, és onnantól kezdve évről évre mérséklődött a mutató. Ennek vet(ett) véget egy időre a 2020 elején megjelent, majd világméretúvé vált koronavírus-járvány, pontosabban az utóbbi visszaszorítására bevezetett korlátozások, valamint a gazdasági visszaesés mérséklését célzó állami programok egyenlegrontó hatása. Noha az év végére várható adósságrátákkal kapcsolatban óriási a bizonytalanság, az IMF (2020) áprilisban publikált előrejelzése szerint az euroövezetben a bruttó hazai termék 7,5 százalékkal zsugorodik 2020-ban. Ez azt

\footnotetext{
${ }^{1}$ Köszönjük az anonim lektorok hasznos javaslatait.

${ }^{2}$ A hivatalos álláspont szerint a recesszió az USA-ban 2007 decemberében kezdődött és 2009 júniusában fejeződött be, azaz 18 hónapig tartott. A Nemzetközi Valutaalap kritériumai szerint 2009-ben volt a világgazdaság egészére kiterjedt recesszió.

${ }^{3}$ A fiskális fenntarthatóságról bővebben lásd Burnside (2005), Castro - De Cos (2002), Agnello - Sousa (2009), Presbitero (2010) munkáit.
} 
jelzi, hogy 2019-ben nagy valószínűséggel lezárult az öt évig tartó fiskális konszolidáció, illetve adósságráta-csökkentés időszaka az EU15 országokban. Másképpen fogalmazva, véget ért az az időszak, amely a kedvező konjunkturális körülmények nyomán lehetővé tette a költségvetési mozgásterek bővítését, ami jelentős mértékben határozza meg az egyes országok lehetőségeit a járvány, illetve az ahhoz kapcsolódó gazdasági válság kezelése terén.

Az említett folyamatok jól érzékeltethetők a konkrét számok alapján is. A régi uniós tagállamokban (a továbbiakban EU15) az államadósság-ráta 1974 és 1996 között 24-ről 70 százalékra emelkedett. Ezt követően a mutató a krízis 2007. évi kezdetéig közel 15 százalékponttal mérséklődött. A 2007-2009. évi nemzetközi pénzügyi és gazdasági válság, illetve az azt követő szuverén adósságválságok hatására az EU15 államadósság-rátája 2014-ben ismét, átlagosan 92 százalékra nőtt, 2015 és 2019 között viszont újra közel 10 százalékponttal mérséklődött. Másként fogalmazva, az elmúlt évben véget ért államadósság-csökkentő periódus nem tekinthető példa nélkülinek.

A két időszak közel hasonló ütemű államadósság-csökkenésének hátterében azonban különböző folyamatok állhatnak. Tanulmányunkban ezeket vizsgáljuk. Arra a kérdésre keressük a választ, hogy miben hasonlít és miben tér el egymástól a két periódus, mely tényezők dinamizálták a nagy recesszió előtt az adósságcsökkentést, és melyekre épül a 2010-es évek második felében végrehajtott konszolidáció. A két időszak összevetése nemcsak azért hasznos és tanulságos, hogy jobban megértsük a fiskális jelenségek mögött meghúzódó gazdasági és társadalmi összefüggéseket, hanem azért is, mert a korábbi tapasztalatok választ adhatnak a jelenlegi eseményekkel kapcsolatos kérdéseinkre. A gazdaságpolitikai döntéshozók és a gazdasági szakemberek körében különösen intenzív diskurzus övezte 4 a legutóbbi adósságcsökkentés ütemét és eredményességét, a korábbi tapasztalatok pedig iránymutatásul szolgálhatnak a jövőre nézve, új információkkal és következtetésekkel bővíthetik ismereteinket.

A tanulmány müfaja statisztikai módszerekre (adósságdinamikai dekompozíció) támaszkodó nemzetközi összehasonlító elemzés. Az összehasonlításba az Európai Unió 15 régi tagállamát vontuk be. Ezt azzal indokoljuk, hogy egyrészt egy 15 országból álló minta még viszonylag könnyen kezelhető. Másrészt a maastrichti szerződésben rögzített államháztartási konvergencia-kritériumoknak való megfelelés (a bruttó államadósság nem haladhatja meg a GDP 60 százalékát) és a növekedési és stabilitási paktum továbbfejlesztett rendelkezéseinek teljesítése számottevő külső nyomást gyakorolt a vizsgált tagállamok gazdaság-, azon belül fiskális politikájára, különösen a Gazdasági és Monetáris Unióban. Végül az EU-hoz 2004-ben, 2007-ben, illetve 2013-ban csatlakozott közép-, kelet- és dél-európai országokat azért hagytuk ki az

\footnotetext{
${ }^{4}$ Lásd La Torre - Marsiglio (2019), illetve Bouabdallah és szerzőtársai (2017) munkáit.
} 
összehasonlító elemzésből, mert többségük az 1990-es években a rendszerátalakulási folyamatok következményeivel küszködött, ami fiskális politikáikra, illetve államadósság-pozícióikra is rányomta bélyegét. $A$ tanulmány tudományos újszerüségét az adja, hogy a legutóbbi adósságcsökkentő periódust nem önmagában elemeztük, hanem egy korábbi, nagyobb zavaroktól mentes időszakhoz viszonyítva mutattunk rá a konszolidáció mögötti jellemzőkre és összefüggésekre.

A bevezetés után áttekintjük az adósságcsökkentések lehetséges típusait, majd öszszefoglaljuk, hogy miként alakult az államadósság-ráta a vizsgált időszakokban az EU15 országcsoportban. Ezután mutatjuk be az adósságdekompozíciós vizsgálat menetét és paramétereit, majd az eredmények részletes ismertetésére kerül sor. Az utolsó fejezet az összefoglalást és a következtetéseket tartalmazza.

\section{Az adósságcsökkentések lehetséges típusai}

Az újraelosztás és az allokációs funkció mellett a modern állam egyik legfontosabb feladata a gazdasági stabilitás elősegítése (Musgrave 1959). Ennek részeként a költségvetési politikával szembeni egyik legfontosabb követelmény, hogy válság (például kereslethiányos időszak) esetén képes legyen fiskális élénkítésre (Tóth 2010), azaz az államháztartáson keresztül külső pénzügyi források rendelkezésre bocsátására (Alesina et al. 2008). Mivel ez többnyire állami hitelfelvételek révén valósul meg, ezért a hagyományos nézet szerint a fiskális élénkítés általános irányzatként együtt jár az államadósság növekedésével.

Ezt az álláspontot finomította De Grauwe - Ji (2019) azzal, hogy az EU15 példáján statisztikai adatokkal alátámasztva rámutatott: azokban az országokban, amelyekben a kamatláb meghaladja a GDP-dinamikát, a fiskális expanzió lehetőségei az államadósság-ráta növekedése miatt korlátozottak. Ott viszont, ahol a kamatláb kisebb a GDP-dinamikánál, fiskális élénkítés mellett is stabilizálható, illetve mérsékelhető az államadósság-ráta. Természetesen a kiinduló helyzet, azaz az államadósság-ráta aktuális értéke sem közömbös: minél magasabb, annál korlátozottabb a mozgástér a fiskális lazításra.

Általános irányzatként ahhoz, hogy szükség esetén legyen elég fiskális mozgástere az államnak az eladósodáshoz, elengedhetetlen, hogy a válságok között - különösen a gazdaság prosperálása idején - képes legyen mérsékelni az államadósság-rátát. Erre egyrészt azért van szükség, mert ha az állam a konjunktúraciklus felfelé tartó szakaszában nem csökkenti az adósságrátát, akkor könnyen előállhat az ún. racsni-hatás (P. Kiss 2012). Ez azt jelenti, hogy ha válságban növekszik az adósságráta, a válságmentes periódusokban pedig csupán nem emelkedik tovább, akkor hoszszú távon a válságokhoz kapcsolódó szintugrások miatt az eladósodás folyamatosan nő, ami veszélyezteti az államháztartás fenntarthatóságát (Balatoni 2015, Tóth 2011). Dinamikusan növekvő gazdaságban azonban a költségvetési mozgástér 
megteremtéséhez rövid távon is szükség van szigorú vagy megengedőbben felelősségteljes fiskális politikára, illetve ehhez kapcsolódóan az államadósság-ráta fokozatos mérséklésére. A „,békeidőben” megszerzett befektetői bizalom a válságban megugró finanszírozási igények kielégítésének elengedhetetlen feltétele (Ghosh és szerzőtársai 2013).

Lehmann és szerzőtársai (2020) arra is felhívták a figyelmet, hogy a maastrichti szerződésben rögzített konvergenciakritériumok érvényesítésének feltételei a gazdasági növekedés ütemének és az inflációs rátának az 1990-es évek elejéhez képest bekövetkezett mérséklődése nyomán az utóbbi időben megnehezedtek. A 60 százalékos államadósság-ráta stabilizálásához Nagy és szerzőtársai (2020) szerint a GDP-arányos államháztartási hiánynak 3 százalék helyett 1,1 százaléknak kellene lennie. Lehmann és szerzőtársai (2020) arra is rámutattattak, hogy az uniós fiskális szabályok figyelmen kívül hagyják a főbb nemzetgazdasági szektorok (nem-banki magánszektor, kormányzat és külföld) közötti egyensúlyi követelményeket.

Azokban az országokban, amelyekben az államadósság-ráta magas, annak csökkentése a konjunktúraciklus felfelé ívelő szakaszában olyan általános cél, amelynek megvalósítása jelentősen mérsékli a közpénzügyek sérülékenységét, és javítja a gazdaság következő gazdasági válság hatásaival szembeni ellenállóképességét. Az adósságráta csökkentésének több különböző módja van, amelyeket többféleképpen lehet és érdemes kategorizálni. Bernardini és szerzőtársai (2019) gazdaságpolitikai megközelítéséből kiindulva képeztünk csoportokat az alábbiak szerint:

i. Az elsődleges egyenleg javulása. A szakirodalomban általában „ortodox fiskális kiigazításként" hivatkoznak erre a csatornára, amely adóemelésre, illetve a kiadások visszafogására épül. A legfőbb kérdés ezzel kapcsolatban az, hogy miként hat egy ilyen fiskális kiigazítás a gazdasági növekedésre és a kamatlábak szintjére, illetve e két tényező közvetítésével magára az adósságrátára. Az általános tapasztalat szerint rövid távon a keresleti hatás miatt többnyire csökken a reálnövekedés üteme. Ennek adósságnövelő hatását azonban mérsékelheti a fiskális fegyelem, ami a befektetői bizalom erősödésén keresztül hozzájárul a nominális kamatlábak mérséklődéséhez (Alesina-Perotti 1995, Alesina-Perotti 1997).

ii. Növekedési hatás. A gazdasági növekedés két csatornán keresztül segíti az adósságcsökkentést. Egyrészt a nevezőhatás révén mérsékli az adósságrátát. Másrészt a fellendülő gazdaság több adóbevételt is generál, ami az elsődleges egyenlegen keresztül is lenyomja az adósságrátát akkor, ha ezt a többletbevételt a kormány nem költi el, hanem megtakarítja. A mérés szempontjából azonban gyakran nehéz a második hatás számszerűsítése. Ehhez ugyanis pontosan kellene ismerni a gazdasági növekedés költségvetési egyenlegre gyakorolt hatását, kiszűrve abból a fordított irányú hatást. Bár vannak erre vonatkozó ígéretes kutatások (Mauro - Zilinsky 2016), az adósságráta változásának elemzésekor, így 
az adósságdekompozíciós vizsgálatokban is általában csak a nevezőn keresztül érvényesülő hatást soroljuk ebbe a kategóriába.

iii. Az infláció gyorsulása. A föáramú közgazdasági elméletek szerint a pénzkínálat növelése a gyakorlatban ma már kevésbé elterjedt, de elméletileg lehetséges módja az államadósság monetizálásának. Az elmúlt évek pénzügyi elméletei (endogén pénzteremtés) elutasítják ezt a megközelítést. Ebben a kontextusban az infláció emelkedéséről van szó, nem pedig a pénzkínálat növekedéséről (az utóbbi ugyanis nem feltétlenül okozza az árszínvonal emelkedését). Az árszínvonal növekedése a reálkamatlábak közvetítésével önmagában is csökkenti az adósságrátát, de csak abban az esetben, ha meglepetés-inflációról van szó, és csak olyan mértékben, amilyen arányban az adott állam hosszú lejáratú fix kamatozású hitelekre támaszkodik a finanszírozásban (Aizenman - Marion 2009). Kisebb mértékben, de segítheti az infláció (illetve a GDP-deflátor) gyorsulása az adósságráta csökkentését a nevezőhatáson keresztül is, mert minél nagyobb mértékben bővül a nominális GDP, annál kisebb a hányados (Hall - Sargent 2010).

iv. A kamatlábak csökkenése. Mind a nominális, mind a reálkamatlábak mérséklése csökkenti az adósságrátát. Az előbbi esetben visszaesnek az államadósság éves folyó kiadásainak részét képező kamatkiadások. A kamatlábcsökkentés egyik fontos eszköze az úgynevezett pénzügyi represszió (Reinhart - Rogoff 2009, Reinhart 2012). Minden olyan jogi és egyéb adminisztratív eszköz ide sorolható, amelynek célja az állami hitelfelvétel kamatlábszintjének a lefaragása. Ide tartozhat az államkötvények versenytársainak számító betéti kamatlábak szabályozói oldalról elrendelt maximálása, illetve bizonyos mennyiségú államkötvény-vásárlás különböző biztosítóintézetek számára történő, kötelező jellegű előírása. Ezen túlmenően csökkenthető még a kamatteher az államadósság átstrukturálásával is akkor, ha egy országnak sikerül az államkötvényeit alacsonyabb kamatozású vagy hosszabb futamidejü papírokra cserélni. Ilyenre Európában utoljára Görögországban volt példa (Győrffy 2014). Ehhez hasonló az úgynevezett intézményesítés (mutualization), ami tipikusan az Európai Unión belül fogalmazódott meg, és arra irányul, hogy a piaci hiteleket uniós intézmények finanszírozásával váltsák ki. Utóbbiak a piacról vonnának be forrásokat a közös kezességvállalás miatt a piaci kamatozásnál jóval olcsóbban. A konstrukció először szükségmegoldás volt a szuverén adósságválság kezelésére. Később a Gazdasági és Monetáris Unió továbbfejlesztése kapcsán vetődött fel abban az értelemben, hogy a tagállamok által közösen garantált államkötvényeket kellene kibocsátani. A javaslat elfogadása - elsősorban Németország ellenkezése miatt - nem valószínű. 
v. Privatizáció. Az adósságcsökkentés egyik klasszikus formája az állami vagyon értékesítése. A kulcskérdés ebből a szempontból az, hogy rendelkezik-e az állam olyan vagyonelemekkel, amelyek müködtetése hatékonyabban valósítható meg magántulajdonban. A privatizációs intézkedések eredményessége és hatása leginkább annak a függvénye, hogy milyen áron kerül sor a tranzakcióra. Az általunk elemzett mintába tartozó országok nagy részében ez a hatás elhanyagolható volt.

vi. Árfolyamhatás. Az államadósság úgy is csökkenthető, ha erősödik a hazai valuta árfolyama. Ennek mértéke döntően attól függ, hogy mekkora az államadósságon belül a külföldi devizában fennálló kötelezettség. Az árfolyamhatás révén nemcsak a felvett hitel értéke, hanem ezzel párhuzamosan az évente esedékes nominális kamatköltség is mérsékelhető.

\section{Az államadósság-ráták alakulása}

Ebben a részben részletesen áttekintjük az EU15 országai államadósság-rátájának alakulását a nagy recesszió előtti és a 2019-ben véget ért adósságcsökkentési periódusban. Az első szakasz az 1997 és 2007, a második a 2015 és 2019 közötti időszakot fogja át (1. ábra). A szakaszhatárok mindkét esetben az átlagos adósságráta csökkenésének első és utolsó évét alkotják. Az egyes országok esetében a szakaszokhoz köthető adósságcsökkentő időszakok kezdete és vége is eltérő lehet. Mivel 2008 és 2014 között az átlagos államadósság-ráta emelkedett, ezért ezt a periódust nem vizsgáltuk, kivéve azon országok egyedi esetét, melyekben a második szakasz adósságcsökkentése már ezekben az években elkezdődött. Az egyes országok elemzésénél az első periódus tehát a globális pénzügyi válságot megelőző időszak, míg a második periódus a 2010-es évek.

$A z$ adatok összehasonlíthatósága érdekében végig az Európai Bizottság AMECO adatbázisát használtuk mind a leíró statisztikák esetében, mind pedig a későbbi adósságdinamikai vizsgálat során. Az adatsorok többsége 1995-től áll rendelkezésre, a számításokban figyelembe vett utolsó év pedig 2019. Mivel a tanulmány készítésekor 2019-ről még nem publikáltak tényadatokat, ezért az AMECO-adatbázisból letölthető ${ }^{5}$ legfrissebb uniós előrejelzést használtuk ${ }^{6}$.

A GDP-arányos államadósság tekintetében 1997 és 2019 között a két adósságcsökkentő periódust egy dinamikus adósságráta-emelkedési szakasz választja el egymástól. Az 1990-es évek közepén az átlagos államadósság-ráta az országcsoportban 70 százalék volt, ami innen mérséklődött 2007-re 56 százalékra. Ebben az időszakban összesen négy olyan ország (Görögország, Franciaország, Németország és Portugália) volt, amelynek emelkedett az államadósság-rátája. A növekedés azonban jellemzően

\footnotetext{
${ }^{5} \mathrm{Az}$ adatok letöltésének dátuma: 2019. október 9.

${ }^{6}$ Mivel Dánia esetében az AMECO csak 2000-től tartalmaz adatokat az adósságra vonatkozóan, ezért az ennél hosszabb, országcsoport szinten aggregált adatsorok esetében a dán adatokat nem vettük figyelembe. Az adósságdekompozíciós vizsgálatot azonban természetesen Dánia esetében is elvégeztük a rövidebb idősoron.
} 
ezekben az államokban sem haladta meg a 10 százalékpontot. Ezzel szemben 1997 és 2007 között Írországban például 46 százalékponttal, Belgiumban 41 százalékponttal, Hollandiában és Svédországban pedig egyaránt 30 százalékponttal esett vissza a GDP-arányos államadósság.

A nemzetközi pénzügyi és gazdasági válság, illetve az abból kiinduló euroövezeti szuverén adósságválság hatására az EU15 államadósság-rátája 2014 végére 92 százalékra emelkedett, és onnan csökkent az Európai Bizottság előrejelzése szerint 2019 végén 83 százalékra. Ebben a periódusban csak Franciaország és Olaszország esetében emelkedett az adósságráta, de mindössze néhány százalékponttal. A GDP-arányos államadósság ugyanakkor Î́rországban 43, Hollandiában 19, Németországban 17 százalékponttal mérséklődött 2015 és 2019 között.

\section{1. ábra}

Az EU15 átlagos államadóssága a GDP százalékában

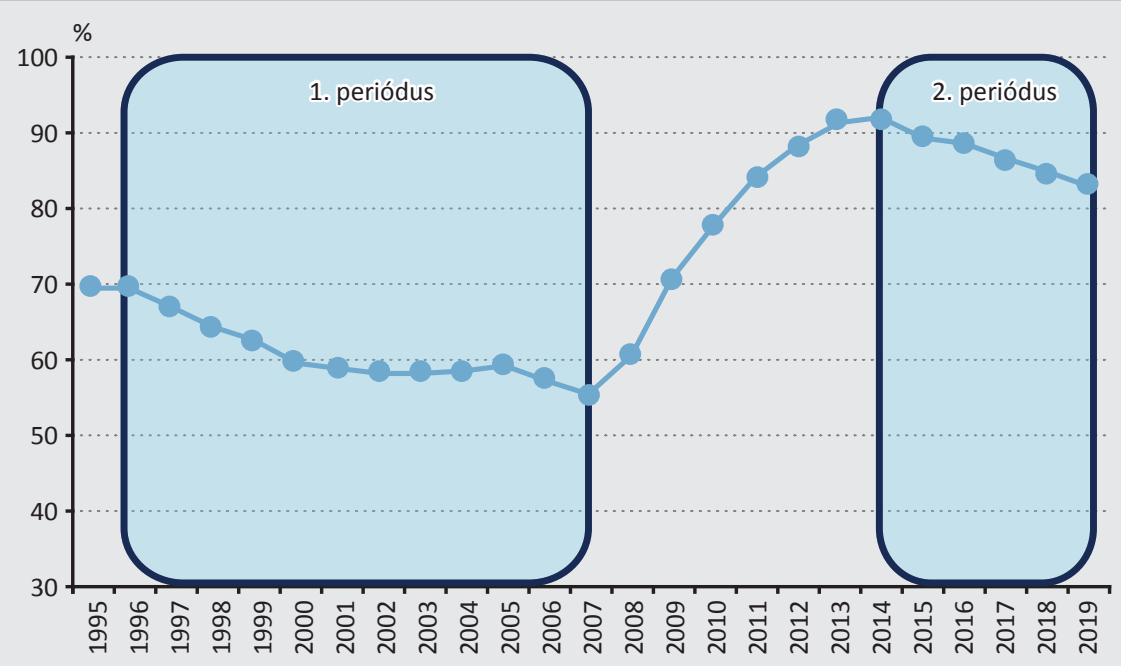

Forrás: $A M E C O$

Bár a vizsgált országok között bőven van hasonlóság az adósságráta dinamikája terén, a mutató szintjében az időszak egészében (is) jelentősek az eltérések. Az államadósság-ráta az első periódusban három országban, Belgiumban, Olaszországban és Görögországban volt kiugróan magas, meghaladta a GDP 100 százalékát. A válság hatására a görög adósságráta rövid idő alatt 160 százalék fölé, az olasz és a portugál mutató pedig 130 százalékra ugrott. A skála másik végén egyrészt Luxemburgot érdemes kiemelni, ahol az államadósság-ráta végig 25 százalék alatt volt, másrészt a hozzá legközelebb álló Svédországot, ahol az 1990-es évek közepén még 70 százalék körül volt a mutató értéke, ami viszont az elmúlt években 40 százalék alá mérséklődött. 
Madártávlatból összegezve a két adósságcsökkentő időszak legfontosabb jellemzőit a teljes országcsoportra megállapítható, hogy amíg az 1997 és 2007 közötti első periódusban az átlagos államadósság-ráta 70 százalék körüli átlagos értékről indulva éves átlagban mintegy 1 százalékponttal csökkent, addig a 2015 és 2019 közötti második periódusban több mint 90 százalékról évente közel két százalékponttal zsugorodott. A következő részben ennek az összetevőit elemezzük.

\section{Az adósság-dekompozíciós vizsgálat}

\subsection{A dekompozíció menete}

A szakirodalomban évtizedek óta nagyon jelentős hangsúlyt kap az államadósság változását befolyásoló tényezők azonosítása és az egyes hatások pontos számszerüsítése. Bár a módszertan tekintetében folyamatosak az újítások (lásd Mauro Zilinsky 2016), az viszonylag régóta igaz, hogy a legtöbb elemzés vagy VAR-modell segítségével próbálja megbecsülni a hatásokat (Hasko 2007, Cherif-Hasanov 2010, Ábel - Kóbor 2011), vagy ún. adósságdinamikai vizsgálattal hajtja végre a dekompozíciót (P. Kiss 1999, De Bolle et al. 2006, Hall - Sargent 2010).

Az előbbi módszer előnye, hogy az egyes hatások számszerűsítése során kontrolálni lehet minden más tényezőre (egyenleg, kamatláb, gazdasági növekedés), és szabadon megválaszthatjuk, hogy mely faktorok hatását szeretnénk vizsgálni. Fontos hangsúlyozni, hogy becslési eljárásról van szó, amely önmagában is számottevő bizonytalanságot hordoz. A megbízható becsléshez hosszú idősorra lenne szükség, ami sokszor nem áll rendelkezésre.

Az általunk a továbbiakban használt adósságdinamikai elemzés számviteli azonosságokra épül, reprodukálható, mert sem a vizsgált időszak hossza, sem más körülmény nem befolyásolja az eredményeket. Az alábbiakban $R a-$ Rhee (2005) és Escolano (2010) munkáira építve vezetjük le az adósságráta változásának dekomponálását.

Az adósságdinamikai vizsgálat során azzal a feltevéssel éltünk, hogy a nominális államadósság alakulását a nominális kamatláb és az elsődleges egyenleg befolyásolja, minden más tényező (például az árfolyamváltozás hatása) az egyéb tételek kategóriájába sorolható. Az inflációval szemben mind a nominális, mind a reálkamatláb előre tekintő, azaz a $t$-edik időszaki adósság(változás) a $t$-1-edik időszaki kamatlábtól (is) függ

$$
B_{t}=\left(1+i_{t-1}\right) B_{t-1}-P B_{t}+S F A_{t},
$$

ahol $B_{t}$ a $t$-edik időszaki nominális államadósság, $i_{t-1}$ az előző évi nominális kamatláb, $P B_{t}$ elsődleges egyenleg (primary balance), az $S F A_{t}$ az egyéb tétel (stock-flow adjustment). Mivel az államadósságot jellemzően a bruttó hazai össztermék százalékában szokták felírni, ezért mindkét oldalt elosztjuk a t-edik évi GDP-vel $\left(Y_{t}\right)$. 


$$
\frac{B_{t}}{Y_{t}}=\frac{\left(1+i_{t-1}\right) B_{t-1}}{Y_{t}}-\frac{P B_{t}}{Y_{t}}+\frac{S F A_{t}}{Y_{t}}
$$

és kifejezzük $Y_{t}$-t az $Y_{t-1}$ segítségével:

$$
\frac{B_{t}}{Y_{t}}=\frac{\left(1+i_{t-1}\right) B_{t-1}}{\left(1+g_{t}\right)\left(1+\pi_{t}\right) Y_{t-1}}-\frac{P B_{t}}{Y_{t}}+\frac{S F A_{t}}{Y_{t}},
$$

ahol $g_{t}$ a reálnövekedést, $\pi_{t}$ az inflációt jelöli.

A GDP-arányos mutatókat kisbetűkkel jelöljük, ennek megfelelően az államadósság $b_{t}$, az elsődleges egyenleg $p b_{t}$, az egyéb tétel pedig $s f a_{t}$

$$
c=\frac{\left(1+i_{t-1}\right)}{\left(1+g_{t}\right)\left(1+\pi_{t}\right)} b_{t-1}-p b_{t}+s f a_{t}
$$

A következő lépésben mindkét oldalból kivonjuk a t-1-edik időszaki adósságrátát, és megkapjuk az adósságráta változását:

$$
\begin{gathered}
\Delta b_{t}=\frac{\left(1+i_{t-1}\right)}{\left(1+g_{t}\right)\left(1+\pi_{t}\right)} b_{t-1}-b_{t-1}-p b_{t}+s f a_{t} \\
\Delta b_{t}=\left[\frac{\left(1+i_{t-1}\right)}{\left(1+g_{t}\right)\left(1+\pi_{t}\right)}-1\right] b_{t-1}-p b_{t}+s f a_{t} \\
\Delta b_{t}=\left[\frac{\left(1+i_{t-1}\right)}{\left(1+g_{t}\right)\left(1+\pi_{t}\right)}-\frac{\left(1+g_{t}\right)\left(1+\pi_{t}\right)}{\left(1+g_{t}\right)\left(1+\pi_{t}\right)}\right] b_{t-1}-p b_{t}+s f a_{t} \\
\Delta b_{t}=\left[\frac{\left(1+i_{t-1}\right)-\left(1+g_{t}\right)\left(1+\pi_{t}\right)}{\left(1+g_{t}\right)\left(1+\pi_{t}\right)}\right] b_{t-1}-p b_{t}+s f a_{t} \\
\Delta b_{t}=\left[\frac{\left.i_{t-1}-g_{t}-\pi_{t}-g_{t} \pi_{t}\right)}{\left(1+g_{t}\right)\left(1+\pi_{t}\right)}\right] b_{t-1}-p b_{t}+s f a_{t} \\
\left.\frac{-g_{t}}{\left(1+g_{t}\right)\left(1+\pi_{t}\right)}\right) b_{t-1}+\left(\frac{i_{t-1}}{\left(1+g_{t}\right)\left(1+\pi_{t}\right)}\right) b_{t-1}+\left(\frac{-\pi_{t}}{\left(1+\pi_{t}\right)}\right) b_{t-1}-p b_{t}+s f a_{t}
\end{gathered}
$$

A (10) egyenlet jobboldalán található az adósságráta változásának dekomponálása sorrendben az alábbi tételekre:

- reálnövekedés

- nominális kamatláb

- inflációs ráta

- elsődleges költségvetési egyenleg

- egyéb tételek (privatizáció, árfolyam stb.) 
Ahhoz, hogy az eredményeket megfelelően tudjuk értelmezni, érdemes még néhány dologra felhívni a figyelmet. Egyrészt, ha összeadjuk a nominális kamatláb pozitív és az infláció negatív hatását, akkor megkapjuk a reálkamatláb hatását. Ez azért fontos, mert a szakirodalomban kitüntetett szerepe van a dinamikus tagnak, vagy - ahogy másként nevezik - a hólabdahatásnak, ami a reálkamatláb és a reálnövekedés együttes hatása. A dinamikus tag azért fontos, mert ennek az előjele határozza meg, hogy az adósságráta stabilizálásához az elsődleges egyenlegnek többletet kell-e mutatnia, ha feltételezzük, hogy az egyéb hatások összege nulla. Emellett a reálnövekedés és a reálkamatláb különbségét nagyon gyakran használják az adósságdinamika fenntarthatóságának a mérésére (Mellár 2002).

A (10) egyenlet értelmezéséhez az is hozzáfüzhető, hogy mivel ez statikus számviteli azonosságokra épülő módszer, ezért az elsődleges egyenleg hatása tartalmazza a reálnövekedés gyorsulásából fakadó egyenlegjavulást, illetve a reálnövekedés lassulásából vagy hiányából fakadó egyenlegromlást. A növekedési hatás pedig magában foglalja a költségvetési keresletélénkítés, illetve keresletszúkítés hatását. Másként fogalmazva, ez a módszer csak a közvetlen hatásokat képes mérni, azt egyrészt, hogy a kormány évről évre mekkora elsődleges hiánnyal növeli, vagy elsődleges többlettel csökkenti az adósságot, másrészt azt, hogy a reálnövekedés a nevezőn keresztül miként hat az adósságrátára. Az egyéb hatásokat a szakirodalomban található nemzetközi gyakorlattal összhangban álló módon számoljuk ki, ide soroljuk minden olyan tényező hatását, amely a többiben nem szerepel (privatizáció, árfolyamhatás stb.).

\subsection{Az adósságdekompozíciós vizsgálat paraméterei}

Az adósságdinamikai vizsgálat célja, hogy a bemutatott módszertan alapján azonosítsuk, a felsorolt tényezők közül melyik, milyen mértékben befolyásolta az államadósság-ráta alakulását. Nem a teljes időszakot és nem az összes országot vizsgáltuk, hanem csak azokat az éveket és országokat, amikor és ahol az államadósság-ráta mérséklődött. Ez azt jelenti, hogy országonként definiáltunk egy válság előtti és egy válság utáni adósságcsökkentő időszakot, ha volt ilyen. Ezeknek az adósságcsökkentő időszakoknak az alábbi feltételeket kellett teljesíteniük:

- Legalább három évig folyamatosan zsugorodik a GDP-arányos államadósság.

- Az adósságcsökkentő időszakban az államadósság-ráta évente átlagosan legalább a GDP 0,5 százalékával csökken.

- Az adósságcsökkentő időszakban a GDP-arányos államadósság összesen legalább 3 százalékponttal esett vissza.

- Az adósságcsökkentő időszakban legfeljebb két olyan év van, amikor nem csökken az adósságráta, de a mutató emelkedése ekkor sem nagyobb, mint az egész időszakban bekövetkezett zsugorodás 20 százaléka. 
Az első periódusban a 15 régi EU-tagország közül 11-ben volt olyan adósságcsökkentő időszak, amely megfelelt a fenti feltételeknek. A vizsgált országok közül csak Görögország, Ausztria, Németország és Luxemburg nem felelt meg ezeknek a kritériumoknak.

\section{1. táblázat}

Államadósság-csökkentő időszakok a globális pénzügyi válság előtt

\begin{tabular}{l|c|c|c|c|c|c|c} 
& $\begin{array}{c}\text { Kezdeti } \\
\text { adósságráta }\end{array}$ & $\begin{array}{c}\text { Záró } \\
\text { adósságráta }\end{array}$ & $\begin{array}{c}\text { Adósságráta } \\
\text { változása }\end{array}$ & $\begin{array}{c}\text { Első } \\
\text { év }\end{array}$ & Utolsó év & $\begin{array}{c}\text { Évek } \\
\text { száma }\end{array}$ & $\begin{array}{c}\text { Adósságráta } \\
\text { éves } \\
\text { változása }\end{array}$ \\
\hline (GDP \%) & (GDP \%) & (GDP \%) & & & & (GDP \%) \\
\hline Delgium & 128,0 & 87,0 & $-40,9$ & 1997 & 2007 & 11 & $-3,7$ \\
\hline Írország & 49,1 & 27,3 & $-21,7$ & 2003 & 2007 & 5 & $-4,3$ \\
\hline Spanyolország & 69,9 & 23,6 & $-46,2$ & 1997 & 2006 & 10 & $-4,6$ \\
\hline Franciaország & 65,6 & 35,6 & $-30,0$ & 1997 & 2007 & 11 & $-2,7$ \\
\hline Olaszország & 116,3 & 99,8 & $-16,5$ & 1997 & 2007 & 11 & $-1,5$ \\
\hline Hollandia & 70,7 & 43,0 & $-27,7$ & 1997 & 2007 & 11 & $-2,5$ \\
\hline Portugália & 59,5 & 50,3 & $-9,2$ & 1997 & 2000 & 4 & $-2,3$ \\
\hline Finnország & 56,1 & 32,7 & $-23,5$ & 1995 & 2007 & 13 & $-1,8$ \\
\hline Svédország & 70,2 & 37,7 & $-32,4$ & 1997 & 2008 & 12 & $-2,7$ \\
\hline Egyesült Királyság & 44,7 & 34,3 & $-10,4$ & 1996 & 2001 & 6 & $-1,7$ \\
\hline ÁTLAG & 72,0 & 48,2 & $-23,8$ & 1997 & 2005 & 9 & $-2,6$ \\
\hline
\end{tabular}

Forrás: Az AMECO adatai alapján összeállítva

Az adósságcsökkentő időszakok között minden dimenzióban voltak jelentős eltérések mind az időbeni lefutás, mind az adósságcsökkentés mértéke tekintetében (1. táblázat). A vizsgálatba bekerült 11 ország 11 adósságcsökkentő időszaka kezdetén az átlagos államadósság-ráta 72,0 százalék volt, ami az időszak végére 23,8 százalékponttal átlagosan 48,2 százalékra esett vissza. A legnagyobb mértékű adósságráta-csökkentés közel 50 százalékponttal Írországban volt, de meghaladta a 40 százalékpontot Belgiumban is, míg a legkisebbre 3,1 százalékponttal Franciaországban került sor.

Az adósságcsökkentés jellemzően 1998 előtt kezdődött. Ez alól csak Dánia volt kivétel, ahol 2003-ban indult. Az adósságcsökkentésnek jellemzően az euro 1998-ban kezdődött bevezetése, illetve a globális pénzügyi és gazdasági válság kitörése vetett véget. Az euro bevezetése előtt az érintett országok eleget tettek az államadósságra vonatkozó konvergenciakövetelménynek. A Gazdasági és Monetáris Unió megvalósítása után viszont ez a nyomás átmenetileg enyhült. Az államadósság-csökkentési 
időszak a legtovább, 13 évig Finnországban, a legrövidebb ideig, 4 évig Portugáliában és Franciaországban tartott, míg az átlag 9 év volt.

Az egy évre jutó adósságcsökkentés mértékét tekintve Îrország és Dánia állt az első helyen 4,6, illetve 4,3 százalékponttal, a sor végén 0,8 százalékponttal Franciaország volt (1. táblázat). Az első periódus 11 évében a GDP-arányos államadósság évente átlagosan 2,6 százalékponttal mérséklődött.

A 2010-es években tíz országban volt olyan adósságcsökkentési időszak, amely megfelelt a vázolt feltételeknek. Olaszország, Franciaország, Görögország, Luxemburg és az Egyesült Királyság volt a kivétel (2. táblázat). A kezdő évben 84,8 százalék volt az átlagos adósságráta, amely 16,6 százalékponttal 68,1 százalékra esett vissza. A legjobb teljesítményt Írország nyújtotta 58,6 százalékponttal, a rangsorban a második 23,4 százalékponttal Németország volt, míg a legkisebb, 4,1 százalékpontos adósságráta-csökkentés Spanyolországban történt.

2. táblázat

Adósságcsökkentő időszakok a 2010-es években

\begin{tabular}{l|c|c|c|c|c|c|c} 
& $\begin{array}{c}\text { Kezdeti } \\
\text { adósságráta }\end{array}$ & $\begin{array}{c}\text { Záró } \\
\text { adósságráta }\end{array}$ & $\begin{array}{c}\text { Adósságráta } \\
\text { változása }\end{array}$ & $\begin{array}{c}\text { Első } \\
\text { év }\end{array}$ & Utolsó év & $\begin{array}{c}\text { Évek } \\
\text { száma }\end{array}$ & $\begin{array}{c}\text { Adósságráta } \\
\text { éves } \\
\text { változása }\end{array}$ \\
\hline (GDP \%) & (GDP \%) & (GDP \%) & & & & (GDP \%) \\
\hline Dénia & 107,5 & 101,3 & $-6,2$ & 2015 & 2019 & 5 & $-1,2$ \\
\hline Németország & 46,1 & 33,0 & $-13,1$ & 2012 & 2019 & 8 & $-1,6$ \\
\hline Írország & 119,9 & 58,4 & $-23,4$ & 2011 & 2019 & 9 & $-2,6$ \\
\hline Spanyolország & 100,4 & 91,3 & $-58,6$ & 2013 & 2019 & 7 & $-8,4$ \\
\hline Hollandia & 67,9 & 49,1 & $-18,8$ & 2015 & 2019 & 5 & $-3,8$ \\
\hline Ausztria & 84,7 & 69,7 & $-15,0$ & 2016 & 2019 & 4 & $-3,8$ \\
\hline Portugália & 130,6 & 119,5 & $-11,1$ & 2015 & 2019 & 5 & $-2,2$ \\
\hline Finnország & 63,4 & 58,3 & $-5,1$ & 2016 & 2019 & 4 & $-1,3$ \\
\hline Svédország & 45,5 & 34,4 & $-11,1$ & 2015 & 2019 & 5 & $-2,2$ \\
\hline ÁtLAG & 84,8 & 68,1 & $-16,6$ & 2014 & 2019 & 6 & $-2,8$ \\
\hline Forrás: Az AMECO adatai alapján & & & & & 5 & $-0,8$ \\
\hline
\end{tabular}

A válság utáni adósságcsökkentés jellemzően 2015 körül kezdődött, de Németországban már 2011-ben, míg Finnországban és Ausztriában csak 2016-ban. Az utolsó vizsgált év 2019, nem csupán azért, mert erre az évre vonatkozóan a jelenlegi számok vélhetően már nem térnek el érdemben a végleges értékektől, hanem azért is, mert a koronavírus-járvány véget vet ennek a konszolidációs időszaknak is. Ennek megfelelően az adósságcsökkentési időszakok hossza átlagosan 6 év volt. Az egy 
évre jutó adósságcsökkentésben szintén Írország vezet 8,4 százalékponttal, mögötte, jócskán leszakadva áll Hollandia és Ausztria 3,8-3,8 százalékponttal, míg a sort Spanyolország zárja 0,8 százalékponttal. A teljes második periódusra és az összes adósságcsökkentő időszakra vonatkozó éves átlagos adósságcsökkentés 2019-ig a GDP 2,8 százaléka volt.

Összefoglalva az eddigieket, a legfontosabb hasonlóság a két periódus között az, hogy egyrészt mindkettőben nagyságrendileg ugyanannyi (10-11) országban volt adósságcsökkentési időszak, másrészt az éves átlagos adósságráta-csökkenés mértéke is hasonló (2,6, illetve 2,8 százalékpont) volt.

Nem volt jelentős az eltérés az adósságráták induló szintjében sem, ami az első periódusban átlagosan 72 százalékra rúgott, a második periódusban 85 százalék volt. Ennél nagyobb volt viszont a különbség az adósságcsökkentő időszakok végén. A hasonló ütemú adósságcsökkentés fényében ez a két vizsgált periódus eltérő hosszára vezethető vissza (9, illetve 6 év).

\section{Eredmények}

\section{1. Átlagos hatások}

Az alábbiakban előbb részletesen bemutatjuk, hogy a felsorolt tényezők országonként milyen mértékben járultak hozzá az adósságcsökkentéshez külön-külön a két vizsgált periódusban, majd az egyes tényezők relatív hozzájárulása alapján vetjük össze a két időszakot.

Az első periódusról általánosságban elmondható, hogy az adósságcsökkentés hajtóereje kizárólag a fiskális politika, azon belül a költségvetési fegyelem volt (3. táblázat). Az elsődleges egyenleg átlagos adósságcsökkentő hatása (29,5 százalékpont) ugyanis meghaladta az átlagos adósságcsökkentés mértékét ( 23,8 százalékpont). Ez külön-külön is érvényes az országok majdnem kétharmadára, de kiemelten igaz Finnországra, ahol az elsődleges egyenleg adósságmérséklő hatása az adósságráta csökkenésének majdnem háromszorosa volt. Portugália volt az egyetlen ország, ahol az elsődleges hiány még az adósságcsökkentés időszakában is emelte az adósságot. A többi vizsgált országban a költségvetési politika nem csupán segítette a kötelezettségállomány mérséklését, hanem élen is járt ebben a folyamatban. 


\begin{tabular}{|c|c|c|c|c|c|c|c|c|}
\hline \multicolumn{9}{|c|}{$\begin{array}{l}\text { Az adósságráta változásának dekompozíciója a GDP százalékában, a globális pénzügyi } \\
\text { válság előtt }\end{array}$} \\
\hline & $\begin{array}{l}\text { Adósság- } \\
\text { változás }\end{array}$ & $\begin{array}{l}\text { Elsődleges } \\
\text { egyenleg }\end{array}$ & $\begin{array}{c}\text { Reál- } \\
\text { növekedés }\end{array}$ & Infláció & $\begin{array}{l}\text { Nominális } \\
\text { kamat }\end{array}$ & $\begin{array}{l}\text { Egyéb } \\
\text { tételek }\end{array}$ & Hólabda & $\begin{array}{l}\text { Reál- } \\
\text { kamat }\end{array}$ \\
\hline & & (1) & (2) & (3) & (4) & (5) & $(2)+(3)+(4)$ & $(3)+(4)$ \\
\hline Belgium & $-40,9$ & $-55,8$ & $-29,0$ & $-21,3$ & 68,0 & $-2,8$ & 17,7 & 46,7 \\
\hline Dánia & $-21,7$ & $-27,6$ & $-4,0$ & $-3,5$ & 10,4 & 3,1 & 2,8 & 6,9 \\
\hline Írország & $-46,2$ & $-36,6$ & $-29,1$ & $-12,3$ & 15,0 & 16,7 & $-26,3$ & 2,7 \\
\hline Spanyolország & $-30,0$ & $-24,6$ & $-21,6$ & $-16,4$ & 29,0 & 3,6 & $-9,0$ & 12,7 \\
\hline Olaszország & $-16,5$ & $-31,8$ & $-17,4$ & $-25,1$ & 63,9 & $-6,1$ & 21,4 & 38,8 \\
\hline Hollandia & $-27,7$ & $-22,6$ & $-17,4$ & $-12,7$ & 31,9 & $-6,9$ & 1,8 & 19,2 \\
\hline Portugália & $-9,2$ & 1,4 & $-8,6$ & $-5,3$ & 12,5 & $-9,1$ & $-1,5$ & 7,1 \\
\hline Finnország & $-23,5$ & $-64,3$ & $-23,2$ & $-9,3$ & 35,0 & 38,3 & 2,6 & 25,8 \\
\hline Svédország & $-32,4$ & $-44,0$ & $-20,0$ & $-7,7$ & 32,9 & 6,4 & 5,2 & 25,2 \\
\hline Egyesült Királyság & $-10,4$ & $-12,5$ & $-7,8$ & $-4,7$ & 17,1 & $-2,4$ & 4,5 & 12,4 \\
\hline Franciaország & $-3,1$ & $-5,7$ & $-7,5$ & $-2,7$ & 13,2 & $-0,5$ & 3,0 & 10,5 \\
\hline ÁTLAG & $-23,8$ & $-29,5$ & $-16,9$ & $-11,0$ & 29,9 & 3,6 & 2,0 & 18,9 \\
\hline
\end{tabular}

A fegyelmezett fiskális politikától eltérően a hólabdahatás nem járult hozzá érdemben az adósságráta csökkentéséhez. Az átlagos folyamatokat tekintve a reálnövekedés adósságmérséklő hatását éppen ellensúlyozta a reálkamatláb hatása. Ebben a vonatkozásban azonban itt nagyobb eltérések vannak az egyes országok között. Amíg a hólabdahatás Olaszországban és Belgiumban a magas kamatlábak miatt közel 20 százalékponttal növelte az adósságrátát, addig Spanyolországban közel 10 százalékponttal, Írországban pedig közel 30 százalékponttal mérsékelte. Mindkét utóbbi országra érvényes, hogy a gazdasági növekedés adósságcsökkentő hatása meghaladta az átlagot, a reálkamatláb adósságnövelő hatása pedig elmaradt attól. A hólabdahatáshoz hasonlóan az egyéb tételek sem befolyásolták érdemben a vizsgált országok átlagában az adósságrátát. Kivételként Finnország és Írország említhető, ahol emiatt 38, illetve 17 százalékponttal emelkedett az államadósság-ráta.

Mivel az egyes országokban az adósságcsökkentő időszak eltérő hosszúságú volt, ezért érdemes az egy évre jutó dekompozíciót is megvizsgálni (4. táblázat). Ebből az tűnik ki, hogy a fiskális politika leginkább - évente több mint 5 százalékponttal Belgiumban és Dániában támogatta az adósságráta csökkenését, míg Portugáliában évente 0,2 százalékponttal mérsékelte. A reálnövekedés tekintetében éllovas Írország és Belgium esetében a gazdaság bővülésének hozzájárulása évente 2,5-3 százalékpontot tett ki, míg ez Dániában mindössze 0,8 százalékpont volt. A reálkamatláb 
Írországban évente csak 0,3 százalékponttal növelte a GDP-arányos államadósságot, míg Belgiumban 4,2 százalékponttal. Az egyéb tényezők Finnországban évente majdnem 3 százalékponttal, Írországban 1,7 százalékponttal emelték évente az adósságrátát, míg Portugáliában több mint 2 százalékponttal csökkentették.

\section{4. táblázat}

Az adósságráta változásának dekompozíciója éves átlagban, a GDP százalékában, a globális pénzügyi válság előtt

\begin{tabular}{l|c|c|c|c|c|c|c|c} 
& $\begin{array}{c}\text { Adósság- } \\
\text { változás }\end{array}$ & $\begin{array}{c}\text { Elsődleges } \\
\text { egyenleg }\end{array}$ & $\begin{array}{c}\text { Reál- } \\
\text { növekedés }\end{array}$ & Infláció & $\begin{array}{c}\text { Nominális } \\
\text { kamat }\end{array}$ & $\begin{array}{c}\text { Egyéb } \\
\text { tételek }\end{array}$ & Hólabda & $\begin{array}{c}\text { Reál- } \\
\text { kamat }\end{array}$ \\
\cline { 3 - 9 } & $\mathbf{( 1 )}$ & $\mathbf{( 2 )}$ & $\mathbf{( 3 )}$ & $\mathbf{( 4 )}$ & $\mathbf{( 5 )}$ & $\mathbf{( 2 ) + ( 3 ) + ( 4 )}$ & $\mathbf{( 3 ) + ( 4 )}$ \\
\hline Belgium & $-3,7$ & $-5,1$ & $-2,6$ & $-1,9$ & 6,2 & $-0,3$ & 1,6 & 4,2 \\
\hline Dánia & $-4,3$ & $-5,5$ & $-0,8$ & $-0,7$ & 2,1 & 0,6 & 0,6 & 1,4 \\
\hline Írország & $-4,6$ & $-3,7$ & $-2,9$ & $-1,2$ & 1,5 & 1,7 & $-2,6$ & 0,3 \\
\hline Spanyolország & $-2,7$ & $-2,2$ & $-2,0$ & $-1,5$ & 2,6 & 0,3 & $-0,8$ & 1,2 \\
\hline Olaszország & $-1,5$ & $-2,9$ & $-1,6$ & $-2,3$ & 5,8 & $-0,6$ & 1,9 & 3,5 \\
\hline Hollandia & $-2,5$ & $-2,1$ & $-1,6$ & $-1,2$ & 2,9 & $-0,6$ & 0,2 & 1,7 \\
\hline Portugália & $-2,3$ & 0,4 & $-2,2$ & $-1,3$ & 3,1 & $-2,3$ & $-0,4$ & 1,8 \\
\hline Finnország & $-1,8$ & $-4,9$ & $-1,8$ & $-0,7$ & 2,7 & 2,9 & 0,2 & 2,0 \\
\hline Svédország & $-2,7$ & $-3,7$ & $-1,7$ & $-0,6$ & 2,7 & 0,5 & 0,4 & 2,1 \\
\hline Egyesült Királyság & $-1,7$ & $-2,1$ & $-1,3$ & $-0,8$ & 2,8 & $-0,4$ & 0,8 & 2,1 \\
\hline Franciaország & $-0,8$ & $-1,4$ & $-1,9$ & $-0,7$ & 3,3 & $-0,1$ & 0,8 & 2,6 \\
\hline ÁTLAG & $-2,7$ & $-3,3$ & $-1,9$ & $-1,2$ & 3,4 & 0,4 & 0,2 & 2,1 \\
\hline
\end{tabular}

Forrás: Az AMECO adatai alapján számítva

Más képet kapunk, ha megvizsgáljuk a második periódusban lezajlott 10 adósságcsökkentő időszakot. Az adósságdinamikai vizsgálat szerint az adósságráta átlagosan 16,6 százalékos csökkentésének alig több, mint egyharmadát, átlagosan 6,1 százalékpontot magyaráz a fiskális politika (5. táblázat). Nincs egyetlen olyan ország sem, ahol az elsődleges többlet hatása meghaladná a teljes adósságráta-csökkentést. A fiskális politika Spanyolországban növelte az adósságrátát, Írországban és Finnországban pedig érdemben nem redukálta. 


\begin{tabular}{l} 
5. táblázat \\
\begin{tabular}{l|c|c|c|c|c|c|c|c} 
Az adósságráta változásának dekompozíciója a GDP százalékában, a 2010-es években \\
& $\begin{array}{l}\text { Adósság- } \\
\text { változás }\end{array}$ & $\begin{array}{c}\text { Elsődleges } \\
\text { egyenleg }\end{array}$ & $\begin{array}{c}\text { Reál- } \\
\text { növekedés }\end{array}$ & Infláció & $\begin{array}{c}\text { Nominális } \\
\text { kamat }\end{array}$ & $\begin{array}{c}\text { Egyéb } \\
\text { tételek }\end{array}$ & Hólabda & $\begin{array}{c}\text { Reál- } \\
\text { kamat }\end{array}$ \\
\cline { 3 - 11 } & & $\mathbf{( 1 )}$ & $\mathbf{( 2 )}$ & $\mathbf{( 3 )}$ & $\mathbf{( 4 )}$ & $\mathbf{( 5 )}$ & $\mathbf{( 2 ) + ( 3 ) + ( 4 )}$ & $\mathbf{( 3 ) + ( 4 )}$ \\
\hline Belgium & $-6,2$ & $-5,1$ & $-7,7$ & $-8,8$ & 15,9 & $-0,5$ & $-0,6$ & 7,1 \\
\hline Dánia & $-13,1$ & $-8,6$ & $-5,0$ & $-3,1$ & 11,5 & $-7,9$ & 3,4 & 8,4 \\
\hline Németország & $-23,4$ & $-18,5$ & $-10,8$ & $-8,7$ & 14,0 & 0,5 & $-5,4$ & 5,4 \\
\hline Írország & $-58,6$ & $-5,4$ & $-47,4$ & $-1,7$ & 11,5 & $-15,6$ & $-37,6$ & 9,8 \\
\hline Spanyolország & $-4,1$ & 4,4 & $-13,9$ & $-3,9$ & 15,4 & $-6,2$ & $-2,3$ & 11,6 \\
\hline Hollandia & $-18,8$ & $-7,2$ & $-6,7$ & $-3,7$ & 6,4 & $-7,6$ & $-3,9$ & 2,8 \\
\hline Ausztria & $-15,0$ & $-5,2$ & $-6,8$ & $-5,4$ & 7,9 & $-5,6$ & $-4,2$ & 2,6 \\
\hline Portugália & $-11,1$ & $-9,1$ & $-12,8$ & $-5,7$ & 17,0 & $-0,5$ & $-1,5$ & 11,3 \\
\hline Finnország & $-5,1$ & $-0,3$ & $-5,6$ & $-2,2$ & 3,5 & $-0,5$ & $-4,4$ & 1,3 \\
\hline Svédország & $-11,1$ & $-6,3$ & $-5,4$ & $-2,5$ & 1,2 & 1,9 & $-6,7$ & $-1,3$ \\
\hline ÁTLAG & $-16,6$ & $-6,1$ & $-12,2$ & $-4,6$ & 10,4 & $-4,2$ & $-6,3$ & 5,9 \\
\hline Forrás: Az AMECO adatai & & & & & & & & \\
\hline
\end{tabular} \\
\hline
\end{tabular}

Az átlagot tekintve a hólabdahatás szinte pontosan megegyezett a fiskális politika 6 százalékpont körüli hatásával. Ez azt jelenti, hogy a reálnövekedés adósságráta-csökkentő hatása ebben a periódusban már meghaladta a reálkamatláb adósságráta-növelő hatását. E tekintetben kiugró Írország helyzete, ahol a dinamikus tagra vezethető vissza az adósságráta-csökkentés közel kétharmada. E mögött nagyon jelentős növekedési hatás áll. A dinamikus tag csak Dániában volt pozitív, ami az átlagnál nagyobb kamatlábhatással és az átlagnál kisebb növekedési hatással kapcsolatos.

Az elsődleges egyenleg és a hólabdahatás mellett nem elhanyagolható az egyéb tételek hatása sem, utóbbiak ugyanis átlagosan 4,2 százalékponttal mérsékelték az adósságrátát. Ezen belül is listavezető Írország -15,6 százalékkal (a nemzetközi pénzügyi és gazdasági válság idején az állam által kimentett pénzügyi közvetítők privatizációja miatt). Svédországban viszont az egyéb tételek (elsősorban az árfolyamhatás, a svéd korona euróval szembeni árfolyamának leértékelődése nyomán) összességében érdemben emelték az adósságrátát.

A második periódusban végbement adósságcsökkentések elemzésekor is érdemes évekre lebontva dekomponálni az adósságráta változását. Ezáltal pontosabban összehasonlíthatók az egyes országok (6. táblázat). Az összevetésből kitűnik, hogy az elsődleges egyenleg Dániában és Portugáliában mozdította elő leginkább az államadósság-ráta csökkenését, évente 2,1 , illetve 1,8 százalékponttal, míg 
Spanyolországban a fiskális politika éves átlagban majdnem 1 százalékponttal növelte az adósságrátát.

A reálnövekedés éves hatása Írországban volt messze a legnagyobb (-6,8 százalék), noha Spanyolországban (-2,8 százalék) és Portugáliában (-2,6 százalék) is jelentősnek bizonyult. Dániában viszont a bruttó hazai termék emelkedése éves átlagban alig mérsékelte az államadósság-rátát.

A reálkamatláb adósságráta-növelő hatása Spanyolországban és Portugáliában volt a legnagyobb, évente 2,3 százalékpont. A negatív reálkamatláb miatt ez a tétel évente 0,3 százalékponttal mérsékelte az adósságrátát Svédországban. Az egyéb tételek éves átlagban is Írországot támogatták a leginkább, több mint 2 százalékponttal, míg Svédországban és Németországban évente kismértékben növelték az adósságrátát.

\begin{tabular}{|c|c|c|c|c|c|c|c|c|}
\hline \multicolumn{9}{|l|}{$\begin{array}{l}\text { 6. táblázat } \\
\text { Az adósságr }\end{array}$} \\
\hline & \multirow[t]{2}{*}{$\begin{array}{l}\text { Adósság- } \\
\text { változás }\end{array}$} & $\begin{array}{c}\text { Elsődleges } \\
\text { egyenleg }\end{array}$ & $\begin{array}{c}\text { Reál- } \\
\text { növekedés }\end{array}$ & Infláció & $\begin{array}{c}\text { Nominális } \\
\text { kamat }\end{array}$ & $\begin{array}{l}\text { Egyéb } \\
\text { tételek }\end{array}$ & Hólabda & $\begin{array}{l}\text { Reál- } \\
\text { kamat }\end{array}$ \\
\hline & & (1) & (2) & (3) & (4) & (5) & $(2)+(3)+(4)$ & $(3)+(4)$ \\
\hline Belgium & $-1,2$ & $-1,0$ & $-1,5$ & $-1,8$ & 3,2 & $-0,1$ & $-0,1$ & 1,4 \\
\hline Dánia & $-1,6$ & $-1,1$ & $-0,6$ & $-0,4$ & 1,4 & $-1,0$ & 0,4 & 1,0 \\
\hline Németország & $-2,6$ & $-2,1$ & $-1,2$ & $-1,0$ & 1,6 & 0,1 & $-0,6$ & 0,6 \\
\hline Írország & $-8,4$ & $-0,8$ & $-6,8$ & $-0,2$ & 1,6 & $-2,2$ & $-5,4$ & 1,4 \\
\hline Spanyolország & $-0,8$ & 0,9 & $-2,8$ & $-0,8$ & 3,1 & $-1,2$ & $-0,5$ & 2,3 \\
\hline Hollandia & $-3,8$ & $-1,4$ & $-1,3$ & $-0,7$ & 1,3 & $-1,5$ & $-0,8$ & 0,6 \\
\hline Ausztria & $-3,8$ & $-1,3$ & $-1,7$ & $-1,3$ & 2,0 & $-1,4$ & $-1,1$ & 0,6 \\
\hline Portugália & $-2,2$ & $-1,8$ & $-2,6$ & $-1,1$ & 3,4 & $-0,1$ & $-0,3$ & 2,3 \\
\hline Finnország & $-1,3$ & $-0,1$ & $-1,4$ & $-0,5$ & 0,9 & $-0,1$ & $-1,1$ & 0,3 \\
\hline Svédország & $-2,2$ & $-1,3$ & $-1,1$ & $-0,5$ & 0,2 & 0,4 & $-1,3$ & $-0,3$ \\
\hline ÁTLAG & $-2,9$ & $-1,1$ & $-2,1$ & $-0,8$ & 1,8 & $-0,7$ & $-1,1$ & 1,0 \\
\hline
\end{tabular}

\section{2. Átlagos relatív hozzájárulások}

Az általános jellemzőkhöz képest sokkal nagyobb különbségek vannak külön-külön az egyes tételeknek az adósságráta mérséklésében betöltött szerepe terén. A legjelentősebb különbség a költségvetés körül rajzolódik ki (2. ábra).

Az első periódusban átlagosan az elsődleges egyenleg adósságcsökkentő hatása a teljes adósságcsökkentés 127 százaléka, míg a második periódusban mindössze 34 százaléka volt. Mindez ráadásul nem kizárólag egy-két kiugró eredményt nyújtott 
országra volt visszavezethető, hanem általános tendenciának bizonyult. Az első periódusban csak egy ország (Portugália) nem érte el a második periódus átlagát, míg a második periódusban egyetlen ország sem közelítette meg az elsőét. Nem túlzás tehát az a következtetés, amely szerint amíg a válság előtt az adósságcsökkentés kizárólagos motorja a fegyelmezett költségvetési politika volt, addig a válság után radikálisan csökkent az elsődleges egyenleg szerepe.

A két periódusban a költségvetési politika adósságráta-csökkentésben betöltött eltérő funkciója értelemszerűen rányomta bélyegét más tételekre is. A reálkamatláb és a reálnövekedés együttes hatását megragadó hólabdahatás (3. ábra) például ellentétes előjelű a két periódusban. Az első szakaszban, a válság előtt az átlagos hólabdahatás -23 százalék volt. Ez azt jelenti, hogy a reálkamatláb adósságráta-növelő hatása meghaladta a reálnövekedés ezzel ellentétes hatását, tehát a hólabdahatás növelte az adósságot. Ez, három kivétellel, az összes országra érvényes volt. Ezzel szemben a második szakaszban, a válság után a hólabdahatásból fakadt az átlagos adósságráta-csökkentések közel egyharmada. Egy ország kivételével mindenhol nagyobb volt a reálnövekedés adósság-rátacsökkentő hatása, mint a reálkamatlábé (3. ábra).

\section{2. ábra}

Az elsődleges egyenleg adósságcsökkentő hatása a teljes adósságcsökkentéshez képest

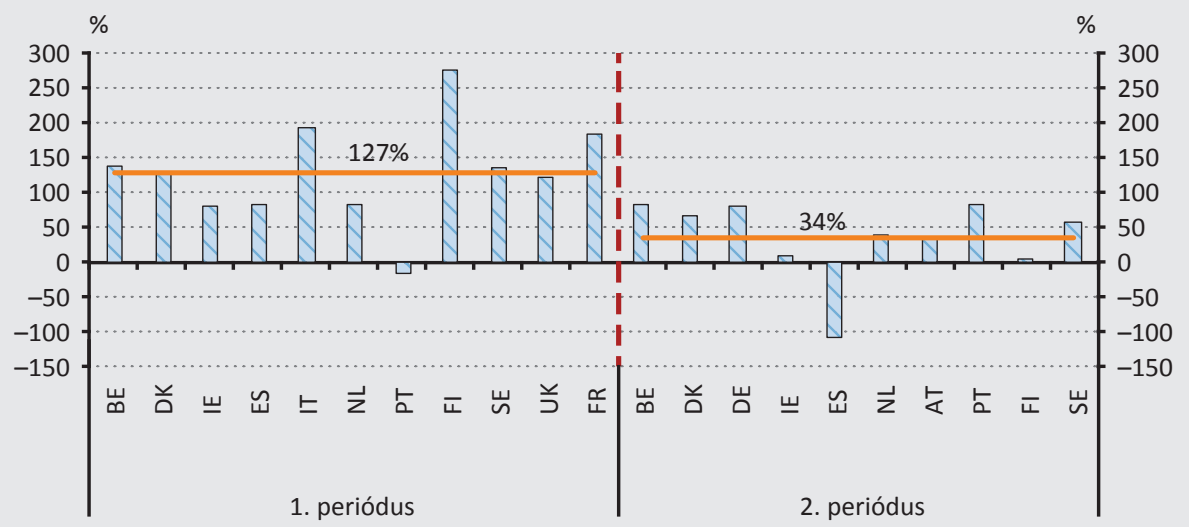

Megjegyzés: A vízszintes vonal a periódus átlaga. A pozitiv érték az adósságcsökkentéshez való hozzájárulást, a negatív az ezzel ellentétes irányú hatást jelzi.

Forrás: Az AMECO adatai alapján számítva 


\section{3. ábra}

A hólabdahatás adósságcsökkentő hatása a teljes adósságcsökkentéshez képest

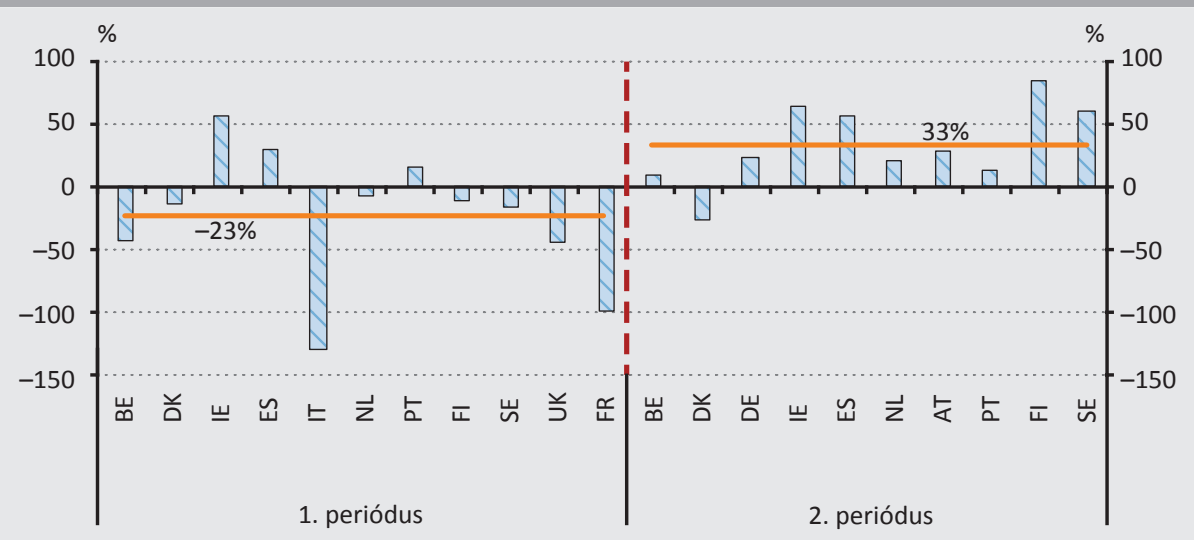

Megjegyzés: A vízszintes vonal a periódus átlaga. A pozitiv érték az adósságcsökkentéshez való hozzájárulást, a negativ az ezzel ellentétes irányú hatást jelzi.

Forrás: Az AMECO adatai alapján számítva

A fenti tételekhez képest kisebb, de azért nem elhanyagolható a különbség az egyéb tételek hatását tekintve sem (4. ábra). Az első periódusban az egyéb tételek összességében, átlagosan -4 százalékkal járultak hozzá az adósságráta csökkentéséhez, azaz hatásuk gyakorlatilag semleges volt. A második peridusban viszont jelentős tényezővé léptek elő, mert átlagosan 32 százalékkal járultak hozzá az adósságráta csökkentéséhez, azaz hasonlóan az elsődlegesegyenleg-, illetve a hólabdahatáshoz, az adósságcsökkentés harmada jutott rájuk. Ezen belül jól jellemzi a trendeket, hogy bár voltak eltérések az egyes államok között, az egyéb tételek hatása egy kivétellel mindenhol pozitív volt.

4. ábra

Az egyéb tételek adósságcsökkentő hatása a teljes adósságcsökkentéshez képest

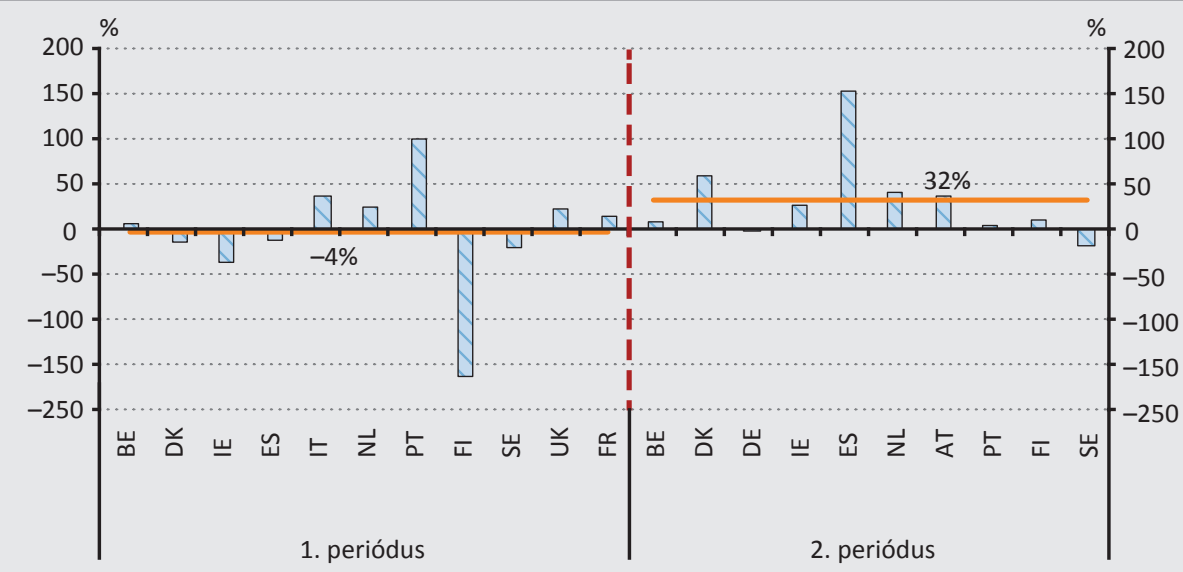

Megjegyzés: A vízszintes vonal a periódus átlaga.

Forrás: Az AMECO adatai alapján számítva 
Ha az egyes tételek átlagos hatását évente külön-külön átlagoljuk, akkor egyértelműen kirajzolódik, hogy miben hasonlít, és miben tér el egymástól a két adósságcsökkentő periódus (5. ábra). Az összehasonlítás alapját többek között az adja, hogy amíg az éves adósságráta-csökkentés mértéke között alig van különbség, addig ez az egyes tételek hozzájárulásáról már nem mondható el. Amíg az első periódusban az elsődleges egyenleg évente átlagosan 3 százalékponttal mérsékelte az adósságrátát, addig a második periódusban már csak 1 százalékponttal.

A hólabdahatás a válság előtt 0,2 százalékponttal növelte, a válság után viszont 1 százalékponttal mérsékelte az adósságrátát. Érdemes hangsúlyozni azonban, hogy ezen belül a reálnövekedés hatásában nem volt jelentős eltérés. Ez a tétel mind a két periódusban hozzávetőleg 2 százalékponttal nyomta le a GDP-arányos államadósságot. A dinamikus tagok közötti különbség ugyanis a reálkamatláb eltérő hatásából adódik, ami pedig a nominális kamatláb és az infláció különbségére vezethető vissza.

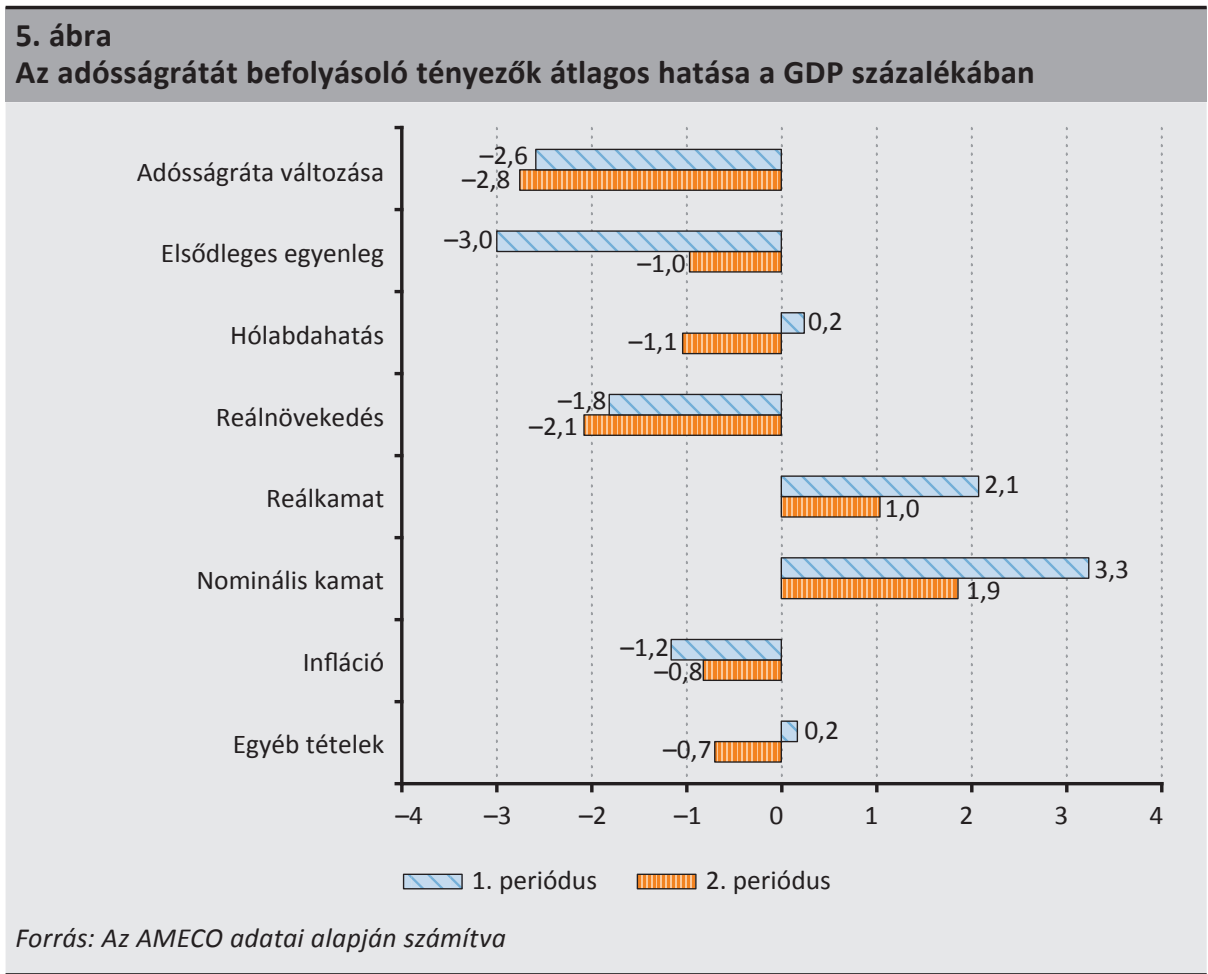

Amíg az első periódusban a nominális kamatláb adósságnövelő hatása 3,3 százalékpont volt, az infláció ezzel ellentétes hatása pedig 1,2 százalékpont, addig a második periódusban a nominális kamatláb befolyása sokkal kisebbnek (1,9 százalékpont), az inflációé pedig csak enyhén kisebbnek (-0,8 százalékpont) bizonyult. Ez azt jelenti, 
hogy az első periódusban jórészt azért volt nagyobb a reálkamatláb hatása, mint a másodikban, mert az infláció befolyása nem volt annyival nagyobb az első periódusban, mint amennyivel nagyobb volt a nominális kamatláb hatása a második periódushoz képest. Másként fogalmazva, a válság utáni adósságcsökkentés részben annak az eredménye, hogy a nominális kamatlábak nagyobb mértékben csökkentek, mint az infláció, és ezért a reálkamatláb adósságnövelő hatása kisebb volt, mint a válság előtt. Illusztrációként megemlíthető, hogy az euroövezetben az egy éves pénzpiaci kamatláb az 1996 és 2007 közötti időszak 3,92 százalékos éves átlagáról 2010 és 2019 között -0,19 százalékra mérséklődött.

A nagy recesszió előtti adósságcsökkentés szerkezetére vonatkozó eredményünk nagymértékben illeszkedik az Európai Bizottság 2010-es kiadványának egy korábbi következtetéséhez (European Commission 2010). Noha ők a teljes euroövezet költségvetési politikájának egy rövidebb időszakát (2003-2007) elemezték, azt találták, hogy a teljes adósságcsökkentéshez képest kétszer nagyobb volt az elsődleges egyenleg hatása, amit részben ellensúlyozott a hólabdahatás és az egyéb tételek összessége. Szintén a teljes euroövezetre és a mi vizsgálatunkhoz képest rövidebb (2015-2018) időszakra vonatkozik a szervezet egy másik elemzése (European Commission 2018) is, amelyben hozzánk hasonlóan ők úgy számolták, hogy az euroövezet országaiban a 2010-es évek második felében végrehajtott adósságcsökkentés fele részben a hólabdahatásra, több mint harmada az elsődleges egyenlegre, közel tizede pedig az egyéb tételekre vezethető vissza.

\section{6. Összefoglalás és következtetések}

Az európai uniós tagállamok államadósság-rátájának 2019-ig tartó csökkentése, illetve ennek eredményessége és szerkezete hosszú időre nagymértékben meghatározza nemcsak a közpénzügyek alakulását, hanem az érintett országok gazdasági növekedését, szélesebb értelemben teljesítőképességét is. Éppen ezért érdemes és tanulságos minél többet megtudni az államadósság-ráták csökkentésének minőségéről, szerkezetéről és sajátosságairól. Elemzésünk célja az államadósság-ráták lefaragása mögötti tényezők és folyamatok feltárása, számszerűsítése és értékelése volt. Az alkalmazott kutatási módszer összehasonlító statisztikai elemzés volt az Európai Unió 15 régi tagállamát tartalmazó minta alapján.

A globális pénzügyi válság előtt, illetve a 2010-es években végrehajtott adósságráta-csökkentés közös vonásaként emelhető ki, hogy az elemzett országok közel kétharmadában volt olyan időszak, amikor több éven keresztül, összességében legalább 3 százalékponttal zsugorodott az államadósság-ráta. A csökkenési szakaszok elején az államadósság-ráták átlagos induló szintje az első periódusban 72 százalék, a másodikban 85 százalék, a végén pedig 48, illetve 68 százalék volt. A csökkentés hossza az első periódusban átlagosan 9 év, a másodikban viszont átlagosan csak 
6 év volt. Ennek eredményeként az átlagos éves adósságráta-csökkentés mértéke az első periódusban 2,8 százalékpont, a másodikban pedig 2,6, azaz gyakorlatilag azonos ütemü volt.

A tanulmányban adósságdinamikai eszközökkel kerestük a választ arra a kérdésre, hogy milyen tényezők mozgatták az adósságráta éves átlagban hasonló ütemú visszafogását a két periódusban, illetve arra, hogy vannak-e eltérések, és ha igen, milyenek, a látszólag hasonló két időszak között ebben a tekintetben. Legfőbb következtetésünk szerint az első periódusban kizárólag a szigorú és fegyelmezett (restriktív) költségvetési politikának volt köszönhető az adósságcsökkentés, míg a reálkamatláb és a reálnövekedés együttesen enyhén növelte az adósságrátát, az egyéb tényezők pedig nem befolyásolták azt érdemben. Ezzel szemben a második periódusban közel azonos (egyenként egyharmad) arányban járult hozzá az adósságráta csökkentéséhez az elsődleges egyenleg, a hólabdahatás és az egyéb tételekbe foglaltak összessége. Fontos kiemelni, hogy a reálnövekedés hatása a két vizsgált időszakban azonos volt, tehát a hólabdahatások közötti eltérést a reálkamatlábak eltérő hatása okozta. Ez pedig arra vezethető vissza, hogy a második időszakban a nominális kamatlábak sokkal alacsonyabbak voltak, mint az elsőben, miközben a két időszak inflációs rátája között nem volt akkora különbség.

Összefoglalásként megállapítható, hogy amíg az első periódusban a költségvetés dinamizálta az adósságráta csökkentését, addig a második időszakban jelentős mértékben gyengült a fiskális politika hatása, és fokozódott az alacsonyabb kamatlábszint, illetve az egyéb tételek szerepe a folyamatban. Ez arra utal, hogy a második periódusban az államadósság-ráta mérséklése inkább a fiskális politikától független tényezőkből táplálkozott, így egyéb faktorok mellett nagymértékben függött a laza monetáris politikától. A jelek szerint a támogató monetáris politika az alacsony reálkamatláb révén elkényelmesíthette a fiskális politikát. Ez a körülmény a monetáris feltételek megváltozása esetén megkérdőjelezi az utóbbi években teret nyert folyamatok hosszú távú fenntarthatóságát. A koronavírus-járvány következményeinek a felszámolásában is a fiskális politika szerepe domborodik ki az egyébként sok tekintetben túlterhelt monetáris politikával szemben.

Tanulmányunk tudományos újszerűsége abban foglalható össze, hogy nem önmagában vizsgáltuk a jelenlegi adósságcsökkentést dinamizáló tényezőket, hanem egy adósságdekompozíciós eljárás segítségével összevetettük egy olyan korábbi időszakkal, amely sok szempontból hasonló volt a mostanihoz. További kutatási irány lehet az általunk közölt eredmények mögött meghúzódó hajtóerők feltérképezése országok szerint. Különösen tanulságos lehet a nemzetközi (IMF, EU) programokba bevont országok fiskális teljesítményének egy nem program-országokból álló kontrollcsoportéval való összehasonlítása. Érdeklődésre tarthat még számot a fiskális politika gazdasági növekedéshez történő hozzájárulásának a vizsgálata (szerkezeti reformok, növekedésösztönző költségvetési beruházások stb.) is. 


\section{Felhasznált irodalom}

Ábel István - Kóbor Ádám (2011): Növekedés, deficit és adósság - fenntartható keretben. Közgazdasági Szemle, 58(6): 511-528.

Agnello, L. - Sousa, R.M. (2009): The Determinants of Public Deficit Volatility. ECB Working Paper No. 1042. European Central Bank. https://www.ecb.europa.eu/pub/pdf/scpwps/ ecbwp1042.pdf

Aizenman, J. - Marion, N. (2009): Using Inflation to Erode the US Public Debt. NBER Working Paper 15562. http://doi.org/10.3386/w15562

Alesina, A. - Campante, F.R. - Tabellini, G. (2008): Why is Fiscal Policy Often Procyclical? Journal of the European Economic Association, 6(5): 1006-1036. https://doi.org/10.1162/ JEEA.2008.6.5.1006

Alesina, A. - Perotti, R. (1995): Fiscal Expansions and Fiscal Adjustments in OECD Countries. NBER Working Papers 5214. http://doi.org/10.3386/w5214

Alesina, A.- Perotti, R. (1997): Fiscal Adjustments in OECD countries: Composition and Macroeconomic Effects. NBER Working Papers 5730. http://doi.org/10.3386/w5730

Balatoni András (2015): A simple fiscal rule for Hungary. Acta Oeconomica, 65(1): 149-159. https://doi.org/10.1556/032.65.2015.s1.9

Baldacci, E. - Gupta, S. - Mulas-Granados, C. (2014): Debt Reduction, Fiscal Adjustment, and Growth in Credit-Constrained Economies. IMF Working Paper No. 13/238. International Monetary Fund. https://doi.org/10.5089/9781475516500.001

Bernanke, B. (2004): The Great Moderation. Az Eastern Economic Association február 20-i találkozóján tartott előadás, Washington D. C. www.federalreserve.gov/boarddocs/ speeches/2004/20040220/default.htm

Bernardini, S. - Cottarelli, C. - Galli, G. - Valdes, C. (2019): Reducing public debt: the experience of advanced economies over the last 70 years. Policy Brief. https://doi. org/10.2139/ssrn.3405018

Bolle, M.B. de - Rother, B. - Hakobyan, I. (2006): The level and composition of public sector debt in emerging market crises. IMF Working Paper No. 6/186. International Monetary Fund. https://www.imf.org/external/pubs/ft/wp/2006/wp06186.pdf

Bouabdallah, O. - Checherita-Westphal, C.D. - Warmedinger, T. - De Stefani, R. - Drudi, F. - Setzer, R. - Westphal, A. (2017): Debt sustainability analysis for euro area sovereigns: a methodological framework. ECB Occasional Paper No. 185. https://www.ecb.europa. eu/pub/pdf/scpops/ecbop185.en.pdf 
Burnside, A.C. (ed.) (2005): Fiscal Sustainability in Theory and Practice: A Handbook. The World Bank Publications. Washington D.C. https://doi.org/10.1596/978-0-8213-5874-0

Castro, F.- De Cos, P.H. (2002): On the Sustainability of the Spanish Public Budget Performance. Revista de Economía Pública, 160(1): 9-27. https://core.ac.uk/download/ pdf/6836082.pdf

Cherif, R. - Hasanov, F. (2010): Public Debt Dynamics and Debt Feedback. MPRA Paper No. 27918. https://mpra.ub.uni-muenchen.de/27918/

Escolano, M.J. (2010): A practical guide to public debt dynamics, fiscal sustainability, and cyclical adjustment of budgetary aggregates. Technical Notes and Manuals, International Monetary Fund. https://doi.org/10.5089/9781462396955.005

European Commission (2010): European Economic Forecast - Spring 2010. European Economy, 2. https://ec.europa.eu/economy_finance/publications/european_ economy/2010/pdf/ee-2010-2_en.pdf

European Commission (2018): European Economic Forecast - Autumn 2018. Institutional paper 089. https://ec.europa.eu/info/sites/info/files/economy-finance/ip089_en_0.pdf

European Commission (2019): Fiscal Sustainability Report 2018. Institutional Paper 094. https://ec.europa.eu/info/sites/info/files/economy-finance/ip094_en_vol_1.pdf

Ghosh, A.- Kim, J.- Mendoza, E. - Ostry, J. - Qureshi, M. (2013): Fiscal fatigue, fiscal space and debt sustainability in advanced economies. The Economic Journal, 123(566): F4-F30. https://doi.org/10.1111/ecoj.12010

Grauwe, P. de - Ji, Y. (2019): Rethinking fiscal policy choices in the euro area. VOX, CEPR Policy Portal, 14 October. https://voxeu.org/article/rethinking-fiscal-policy-choices-euro-area

Győrffy Dóra (2014): Válság és válságkezelés Görögországban: A puha költségvetési korlát szerepe a gazdasági összeomlásban. Közgazdasági Szemle, 61(1): 27-52.

Hall, G.J. - Sargent, T.J. (2010): Interest Rate Risk and Other Determinants of Post-WWII U.S. Government Debt/GDP Dynamics. NBER Working Paper No. 15702. http://doi. org/10.3386/w15702

Hasko, H. (2007): Some Unpleasant Fiscal Arithmetic: The Role of Monetary and Fiscal Policy in Public Debt Dynamics since the 1970s. Bank of Finland Research Discussion Paper 28. https://helda.helsinki.fi/bof/bitstream/handle/123456789/7847/156463. pdf;jsessionid=C501962D1591DA8F0DCCC07B4EA06F64 ?sequence $=1$

IMF (2020): The great lockdown. World Economic Outlook (Chapter 1). International Monetary Fund, Washington. https://www.imf.org/en/Publications/WEO/Issues/2020/04/14/weoapril-2020 
La Torre, D., - Marsiglio, S. (2019). A note on optimal debt reduction policies. Macroeconomic Dynamics, 1-11. http://doi.org/10.1017/S1365100519000014

Lehmann Kristóf - Nagy Olivér - Szalai Zoltán - H. Váradi Balázs (2020): Gazdaságpolitikai ágak közötti koordináció(?) az euroövezetben. Hitelintézeti Szemle, 19(1): 37-64. http:// doi.org/10.25201/HSZ.19.1.3764

Losoncz Miklós (2014): Az államadósság-válság és kezelése az EU-ban. Tri-Mester, Tatabánya.

Mauro, P. - Zilinsky, J. (2016): Reducing government debt ratios in an era of low growth. Policy brief No. PB16-10. Peterson Institute for International Economics. https://www. piie.com/system/files/documents/pb16-10.pdf

Mellár Tamás (2002): Néhány megjegyzés az adósságdinamikához. Közgazdasági Szemle, 49(8): 725-740.

Muraközy László (2012): Államok kora. Az európai modell. Akadémiai kiadó. Budapest.

Musgrave, R.A. (1959): The Theory of Public Finance. New York: McGraw-Hill.

Nagy Olivér - Szalai Zoltán - H. Váradi Balázs (2020): A maastrichti kritériumok-feltételek és feltevések. In: Virág Barnabás (szerk.): Fenntartható felzárkózás euróval - Hogyan újítsuk meg a maastrichti kritériumokat? Magyar Nemzeti Bank, pp. 19-38.

P. Kiss Gábor (1999): A fiskális politika jelzőszámai. Közgazdasági Szemle, 46(4): 307-325.

P. Kiss Gábor (2012): Distinkció és kikényszerithetőség - a fiskális szabályrendszer alfája és ómegája. Pázmány Law Working Papers, 39. sz. http://plwp.eu/docs/wp/2012/2012-39PKiss.pdf

Presbitero, A.F. (2011): Total public debt and economic growth in developing countries. MoFiR working paper No. 44. http://docs.dises.univpm.it/web/quaderni/pdfmofir/Mofir044.pdf

Ra, S. - Rhee, C.Y. (2005): Managing the Debt: An Assessment of Nepal's Public Debt Sustainability. Nepal Resident Mission Working Paper. No. 6. Asian Development Bank, Mandaluyong City. https://think-asia.org/bitstream/handle/11540/3284/wp6. pdf?sequence $=1$

Reinhart, C.M. (2012): The Return of Financial Repression. CEPR Discussion Paper No. DP8947. https://ssrn.com/abstract=2066320

Reinhart, C.M.- Rogoff, K. (2009): This Time is Different. Princeton University Press, Princeton and Oxford.

Tóth, G.Cs. (2014): The Forecasting Capacity of Indicators Measuring Budget Sustainability. Public Finance Quarterly, 56(4): 511-528. 
Tóth G. Csaba (2010): Állami keresletélénkités és automatikus stabilizátorok. Pénzügyi Szemle, 55(1): 51-68.

Tóth G. Csaba (2011): Adósságdinamika és fenntarthatóság. Statisztikai Szemle, 89(12): 1242-1268.

Tóth G. Csaba (2017): A nemzeti költségvetési szabályok elterjedése és hatása Európában. Közgazdasági Szemle, 64(11): 1119-1147. https://doi.org/10.18414/KSZ.2017.11.1119 